\title{
Pelatihan Inovasi Pepaya bagi Perempuan Purna Buruh Migran di Desa Sabrang Kecamatan Ambulu Kabupaten Jember
}

\author{
Lutfi Ariefianto, Muhammad Bahrul Ulum \\ Universitas Jember \\ lutfipls.fkip@unej.ac.id
}

\begin{abstract}
Abstrak
Pepaya menjadi salah satu produk unggulan yang ditekuni oleh para petani di Desa Sabrang, Kecamatan Ambulu, Kabupaten Jember, dengan pertimbangan potensi ekonomi dari hasil panen yang didapatkan. Permasalahan utama yang muncul adalah hasil panen yang tidak dapat dilaksanakan secara bersamaan sehingga menghasilkan inefisiensi dalam proses distribusi hasil panen ke luar daerah. Pada sisi lain, hasil panen melebihi permintaan konsumsi masyarakat setempat sehingga terdapat menurunan nilai produk yang digunakan sebagai makanan ternak. Terhadap permasalahan ini, diperlukan inovasi pengolahan produk papaya ke dalam berbagai macam produk ekonomi sekaligus sebagai upaya pemberdayaan ekonomi masyarakat, khususnya para perempuan purna buruh migran yang tergabung dalam kelompok PPT Desbumi Harmonis di desa setempat. Inovasi dimaksudkan untuk meningkatkan keterampilan bagi perempuan purna buruh migran sehingga dapat mendukung program Desa peduli Buruh Migran (DESBUMI). Upaya ini merupakan bagian dari program pendidikan luar sekolah guna memberikan pengetahuan dan ketrampilan yakni melalui pelatihan inovatif. Pelatihan ini menghasilkan inovasi sabun papaya padat, sabun cair cuci tangan dan lulur yang berbahan papaya.
\end{abstract}

Kata Kunci: Pelatihan Inovasi, Pemberdayaan Masyarakat

\begin{abstract}
Papaya is one of the superior products occupied by farmers in Sabrang Village, Ambulu District, Jember Regency, with consideration of the economic potential of the harvests obtained. The main problem that arises is crop yields that cannot be carried out simultaneously so as to result in inefficiencies in the process of distributing harvests to other regions. On the other hand, yields exceed the consumption demand of the local community so that there is a decrease in the value of products used as animal feed. To this problem, it is necessary to innovate the processing of papaya products into various economic products as well as efforts to empower the community's economy, especially women migrant workers who are members of the Harmonious Indigenous PPT group in the local village. Innovation is intended to improve the skills of women migrant workers so that they can support the Village Migrant Workers (DESBUMI) Village program. This effort is part of an out-of-school education program to provide knowledge and skills
\end{abstract}


through innovative training. This training resulted in the innovation of solid papaya soap, hand washing liquid soap and scrubs made from papaya.

Keywords: Innovation Training, Community Empowerment

\section{PENDAHULUAN}

Desa Sabrang termasuk kategori desa swasembada, swakarya, swamadya di wilayah kecamatan Ambulu Kabupaten Jember. Desa dengan luas kurang lebih 1.120,208 ha ini terletak pada bagian selatan dari Kecamatan Abulu dengan jarak tempuh sekitar 5 kilometer. Desa yang terdiri atas Dusun Kebonsari, Krajan, Tegalreko, Jatirejo dan Ungkalain ini memilik tanah yang subur dengan ketinggian $15 \mathrm{~m}$ dari permukaan air laut. Desai ini memiliki kepadatan penduduk 14.577 Jiwa dengan mayoritas beretnis Jawa. Jumlah angka pendidikan warga tidak sekolah dan putus sekolah cukup tinggi, yaitu mencapai kurang lebih 2,345 jiwa.

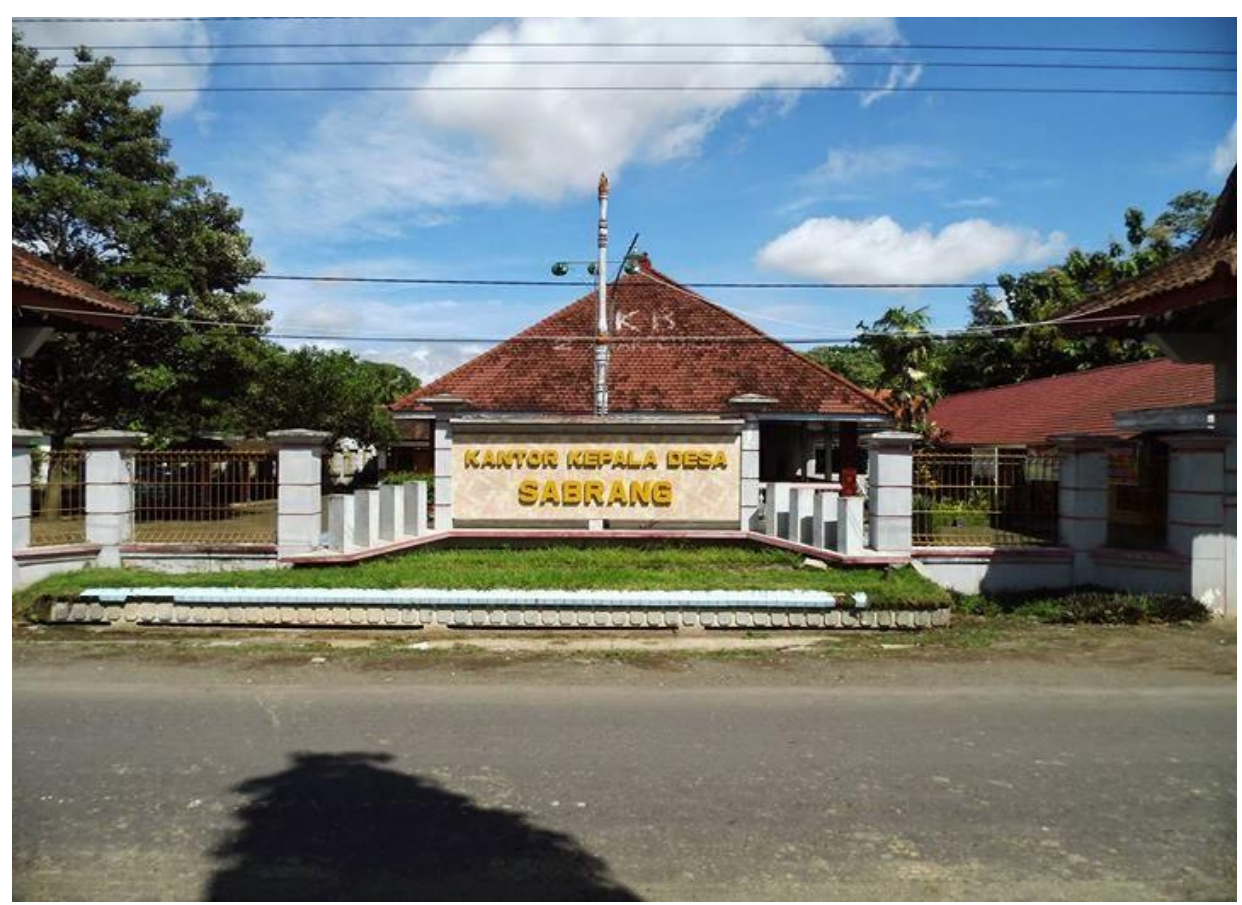

Gambar 1. Kantor Desa Sabrang, Kecamatan Ambulu, Kabupaten Jember

Guna mencukupi kebutuhan keluarga, banyak di antara warga Sabrang memutuskan menjadi buruh migran ke luar negeri, dengan mayoritas perempuan. Di Kecamatan Ambulu, Desa Sabrang memiliki jumlah tertinggi buruh migran yang mencapai 350 jiwa dan profesi lain yang ditekuni masyarakat setempat adalah menjadi petani, pekebun dan peternak dengan prosentase sebesar 79\%. Guna memenuhi kebutuhan hidup, selain menjadi petani dan pekebun, dalam jumlah sedikit, masyarakat setempat berprofesi sebagai guru, pegawai dan pedagang. 
Para petani menjalankan profesinya di bawah binaan Gabungan Kelompok Tani (Gapoktan) Tirto Mulyo. Gapoktan ini memiliki 10 kelompok tani (poktan) di masing-masing dusun. Selain upaya mewujudkan lumbung desa dengan gabah yang saat ini disimpan mencapai kurang lebih 37 ton, para petani di Desa Sabrang memilih diversifikasi tanaman yang sebagian beralih menekuni tanaman papaya. Tanaman papaya California dipilih dengan pertimbangan harga jual yang dinilai lebih tinggi dan cenderung stabil. Hasil panen papaya didistribusikan langsung ke kota-kota besar seperti Jakarta. Hasil panen tanaman pepaya bisa mencapai kurang lebih 20 ton per tahun.

Namun demikian, seiring dengan meningkatnya laju buruh migran ke luar negeri yang berharap perbaikan kualitas kesejahteraan keluarga, mereka memiliki tantangan saat kembali ke kampung halaman. Rendahnya keterampilan berwirausaha dan menekuni industri rumah tangga merupakan masalah yang seringkali dihadapi perempuan purna buruh migran, sehingga potensi ekonomi belum dimanfaatkan dengan baik. Saat ini, Desa Sabrang melalui bimbingan Migran Care Jakarta telah mendirikan Pusat Pelayanan Terpadu (PPT) DESBUMI Harmionis. Lembaga ini berfungsi sebagai wadah para purna buruh migran yang pernah menjadi pahlawan devisa negara untuk diberdayakan serta memberikan bekal bagi calon buruh migran yang hendak berangkat. Berikut gambar tempat Desbumi Harmoni desa Sabrang Kecamatan Ambulu.

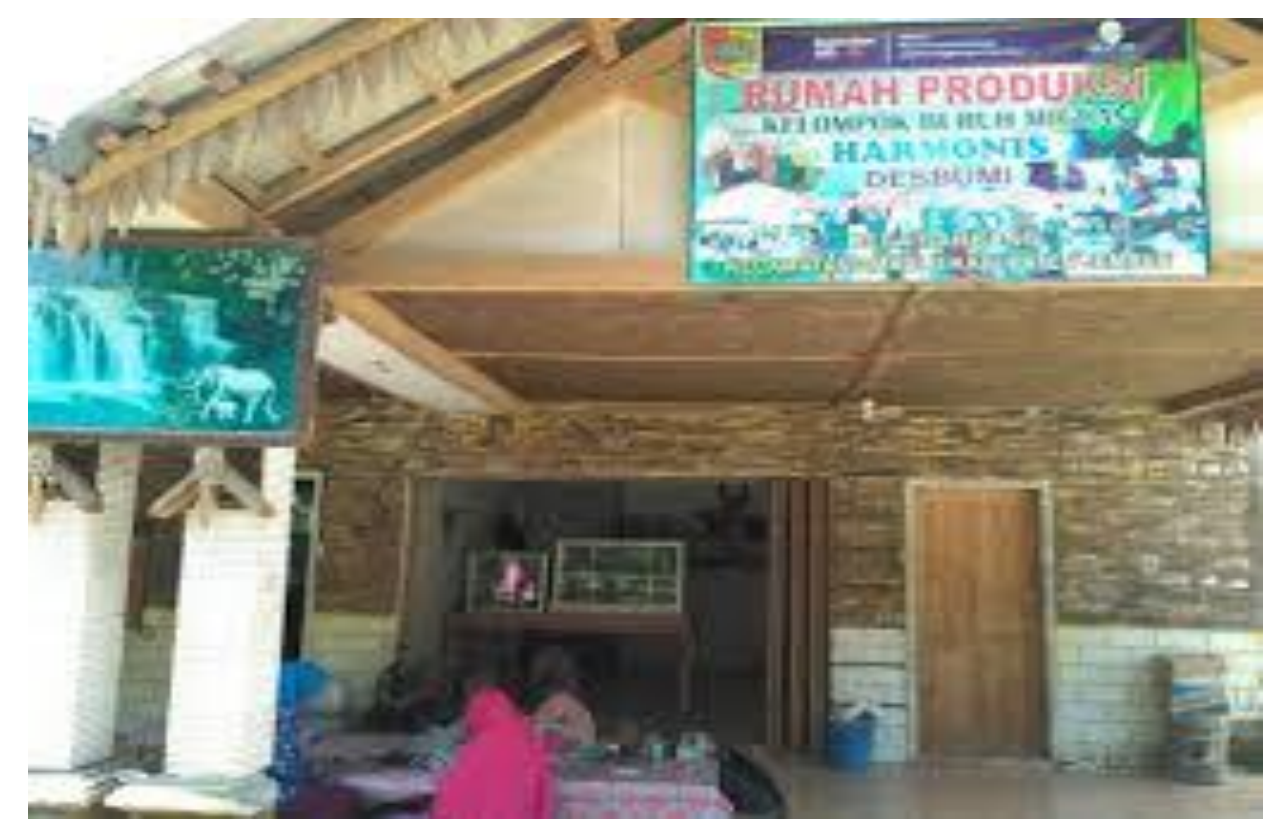

Gambar 2. Tempat Produksi Kelompok Desbumi Harmonis

A. Khalayak Sasaran

Khalayak sasaran dalam program pengabdian kepada masyarakat ini adalah Kelompok perempuan mantan buruh Migran dalam PPT Desbumi Harmonis Desa 
Sabrang, Kecamatan Ambulu untuk mewujudkan Desa Peduli Buruh Migran (DSM). Khalayak sasaran kegiatan ini berjumlah 30 orang yang terdiri dari pengurus dan anggota PPT Desbumi Harmonis.

\section{B. Pendekatan}

Berdasarkan permasalahan yang ditemukan maka tersusun tujuan pengabdian yaitu mengembangkan inovasi berbagai macam produk yang berbahan dasar pepaya yang merupakan hasil pertanian desa sabrang yang melimpah namun menyisakan bahan pepaya yang tidak ikut dalam pengiriman hasil panen ke kota jakarta dan sumtra dengan memberdayakan perempuan-perempuan mantan buruh migran yang tergabung dalam kelompok PPT DESBUMI Harmonis di Desa Sabrang Kecamatan Ambulu Kabupaten Jember melalui kegiatan pelatihan pembuatan macam produk seperti sabun pepaya padat, cair untuk sabun cuci tangan dan sabun lulur pepaya yang mengandung vitamin yang tinggi sangat bagus buat kulit putih dan halus serta yang lebih lagi memiliki nilai produktif, Sehingga metode pendekatan yang digunakan untuk menyelesaikan permasalahan tersebut melalui program-program unggulan yang dimiliki oleh Pendidikan Luar Sekolah yang dibedakan dalam planing better progam : infomasional, institusional and deveopmental. Boyle dalam Moedzakir (2010: 25) yaitu tipe program informasional yakni pemberian penyadaran kepada masyarakat dalam hal ini kelompok perempuan yang tergabung dalam PPT Desbumi Harmoni.

Tipe program Institusional, yakni pemberian Pelatihan ketrampilan setelah disadarkan akan pentingnya potensi yang ada di desa sabrang kecamatan ambulu yakni pepaya yang melimpah yang tidak ikut di panen yang sebagaian besar masih dijadikan seagai pakan ternak untuk di inovasi menjadi berbagai macam produk yang lebih produktif sehingga memiliki nilai ekonomi. tipe Program Developmental, program pengembangan dan pemberdayaan yang ditujukan kepada masyarakat atau komunitas untuk memberdayakan potensi mereka dalam mengatasi masalah kehidupan bersama yang sedang dihadapi.

Berdasarkan analisis situasi, terdapat dua permasalahan utama. Pertama, masyarakat Desa Sabrang memiliki hasil panen papaya yang belum adanya pengolahan guna meningkatkan nilai suatu produk. Pada awalnya, masyarakat cenderung menjual hasil panen yang didistribusikan ke luar daerah, namun pada perkembangannya panen pepaya yang berlangsung tidak secara bersamaan menjadikan produk papaya tidak dapat dilakukan distribusi dengan baik. Pada sisi lain, tidak adanya keterampilan untuk mengubah nilai papaya menjadikan hasil panen dimanfaatkan sebatas pakan ternak. Kedua, masyarakat usia produktif, khususnya purna buruh migran yang tergabung dalam kelompok PPT Desbumi Harmoni Desa Sabrang membutuhkan keterampilan dalam mendayagunakan produk daerahnya. Oleh karena itu, diperlukan program pelatihan keterampilan 
kepada masyarakat setempat guma meningkatkan nilai hasil pertanian guna meningkatkan perekonomian desa.

\section{PEMBAHASAN}

Permasalahan-permasalahan yang ditemukan di Desa sabrang kecamatan membutuhkan solusi-solusi yang akan diimplementasikan dalam kegiatan program pengabdian. Dari permasalahan yang ditemukan yaitu 1) Desa sabrang memiliki produk melimpah berupa pepaya dengan hasil panen melimpah khususnya yang tidak masuk sebagai buah pepaya jenis kalifornia yang normal dan laku dipasaran memerlukan pengembangan inovasi produk-produk hasil pertanian menjadi nilai yang lebih produktif. 2) Keterbatasan keterampilan bagi penduduk desa Sabrang kecamatan Ambulu yang mantan menjadi buruh migran yang tergabung dalam kelompok Desbumi Harmonis karena tingkat pendidikan masyarakat yang masih rendah.

Kegiatan pengabdian ini dilakukan untuk mengembangkan inovasi dari berbagai macam produk yang berbahan papaya seperti sabun pepaya padat, sabun cair cuci tangan, serta lulur kuli dari buah pepaya secara tidak langsung sebagai upaya memberdayakan perempuan-perempuan mantan buruh migran yang tergabung dalam kelompok PPT DESBUMI Harmonis desa sabrang kecamatan Ambulu. Kegiatan ini dilakukan dengan harapan dapat memberikan bekal keterampilan kepada perempuan mantan buruh di Desa sabrang kecamatan ambulu sehingga memiliki aktifitas yang dapat meningkatkan perekonomian demi kesejahteraan keluarga. Pertama, memberikan penyadaran kepada para perempuan mantan buruh migran tentang potensi alam yang berlimbah yakni pepaya yang hanya dianggap sebagai limbah dan pakan ternak bisa di inovasi menjadi macammacam produk yang memiliki nilai produktifitas.

Kedua memberikan pelatihan inovatif macam-macam produk berbahan pepaya seperti sabun pepaya, lulur pepaya dan kripik daun pepaya sehingga secara tidak langsung akan memberikan pengetahuan dan keterampilan baru bagi perempuan mantan buruh migran. Tahap ketiga yaitu memberikan pendampingan terkait tindak lanjut program sehingga akan dapat menanamkan sikap metal wirausaha bagi perempuan mantan buruh migran khususnya tergabung dalam PPT Desbumi Harmonis Desa Sabrang kecamatan Ambulu, sehingga secara tidak langsung kegiatan pemberdayaan ekonomi perempuan akan terwujud. 


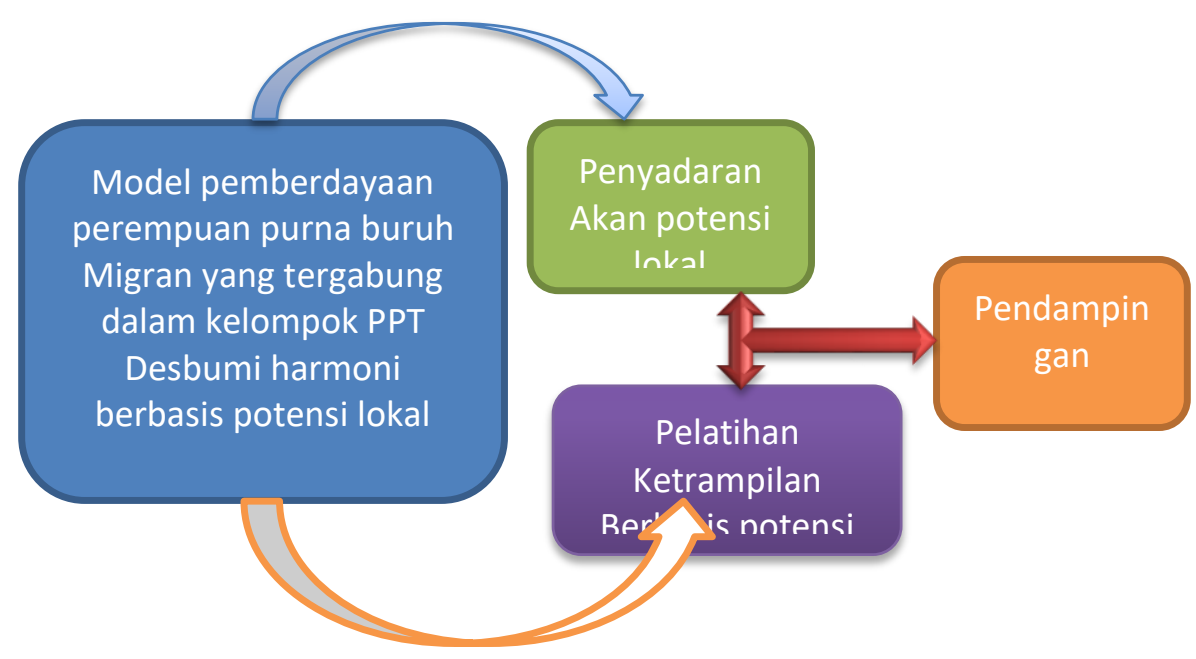

Gambar 3. Skema Solusi Permasalahan

A. Hasil

Kegiatan pengabdian ini nantinya akan memberikan pengetahuan, wawasan dan penguatan kapasistas melalui program pemberdayaan untuk para mantan buruh migran yang pernah memiliki jasa bagai bangsa ini yakni sebagai pahlawan devisa saat bekerja di luar negeri, namun kita wajib memberikan pemberdayaan bagi mereka melalui pembuatan produk yang memiliki nilai ekonomi berasal darihasil potensi daerah/ lokal yang melimpah hasilnya, yakni membuat dan mengolah buah pepaya yang merupakan hasil potensi lokal yang kurang dimanfaatkan menjadi seperti bahan spa/llulur, sabun cair dan sabun mandi yang memiliki fungsi sebagai pemutih dan pengahlus kulit secara alami.

\section{Identifikasi hasil potensi lokal}

Pada kegiatan program pengabdian ini yang sudah dilaksanakan salah satunya adalah mengidentifikasi hasil potensi lokal yang menjadi limbah dan kurang dimanfaatkan oleh warga, disamping itu juga kegiatan yang dilakukan di awal ini yakni berkoordinasi dengan pengurus kelompok PPT Desbumi Harmoni yang ada di desa Sabrang kecamatan Ambulu untuk menentukan lokasi dan kesepakatan hari pelaksanaak kegiatan pelatihan dan penumbuhan jiwa wirausaha bagi para anggota PPT Desbumi Harmoni yang merupakan semua adalah mantan buruh migran yang pernah menjadi pahlawan devisa negara dan perlu adanya program pemberdayaan bagi mereka. 


\section{Penyelenggraan kegiatan pengabdian}

Di samping kegiatan berkoordinasi dengan kelompok PPT Desbumi Harmoni kegiatan yang tidak kalah penting dilaksanakan adalah berkoordinasi tentang manajemen kegiatan pelatihan pembuatan produk sabun pepaya bersama tim, dalam hal ini yakni dengan teman anggota dan mahasiswa dalam merencanakan kegiatan, pelaksanaan kegiatan, serta evaluasi program nantinya dapat melaksanakan kegiatan yang sesuai dengan tujuan yang hendak dicapai.

\section{Pelatihan Pembuatan Sabun Pepaya}

Pelatihan inovasi pembuatan sabun pepaya untuk menjawab pemanfaatan potensi lokal buah pepaya yang sedang melimpah ruah yang hanya sebagai limbah dan pakan ternak semata, yakni di latihkan ketrampilan untuk mengolahnya menjadi sebuah produk yang memiliki nilai ekonomis dan produktif baik digunakan sebagai pemenuhan kebutuhan sendiri, serta diharapkan sebagai suatu produk unggulan yang dilaksakan oleh kelompok perempuan mantan buruh migran yang tergabung dalam PPT Desbumi Harmoni desa Sabrang Kecamatan Ambulu. menyusul produk-produk yang dimiliki sebelumnya sehingga semakin banyak dan dapat diproduksi dan dapat membuat perempuan mantan buruh migran menjadi lebih berdaya secara ekonomi. Pelatihan ini dilaksanakan pada tanggal 01 Desember 2018 yang dilaksanakan di Aula Kantor Desa Sabrang dengan fasilitas yang dibantu oleh kantor desa mulai tempat dan sound system (pengeras suara) selama satu hari full. Adapun agenda pertanya penyampaian materi sharing kekuatan hukum burh migran serta hak-haknya, kemuadian dilanjutkan dengan materi tentang pemberdayaan masyarakat perempuan serta penyadaran akan pentingnya potensi lokal yang perlu di olah dan di manfaatkan menjadi barang yang mimiliki nilai lebih dan produktif. Kemudian dilanjutkan dengan pelatihan dan praktek pembuatan sabun pepaya, dimaka peserta menyimak dan praktek langsung untuk membuat sabun pepaya dengan pendekatan Adult education (pendidikan orang dewasa) dengan mengutamakan bahwa mereka sudah syarat memiliki pengalaman dan tidak mau digurui sesuai dengan sifatnya orang dewasa. Sehingga peserta antusias praktek langsung dalam pembuatan sabun. Secara tidak langsung menambahkan pengetahuan, ketrampilan dan perubahan sikap peserta pelatihan menjadi semnagat dan memiliki jiwa wirausaha dan dapat menghemat dan menambah pendapatannya secara tidak langsung.

\section{Pendampingan dengan metode coaching klinik}

Pendampingan dengan menggunakan metode coaching klinik merupakan kegiatan yang merupakan follow up dari kegiatan pelatihan. Kegiatan ini dilakukan satu minggu setelah kegiatan pelatihan inovasi pembuatan sabun pepaya dalam pemanfaatan poy=tensi lokal yang saat ini hanya sebagai limbah atau pakan tenak 
diolah menjadi produk yang dapat bernilai ekonomis dan produktif yakni produk sabun mandi pepaya, sabun cair cuci tangan dari pepaya serta bahan lulur kulit dengan bahan buah pepaya. Kegiatan ini dilaksanakan pada tanggal 08 Desember 2018 dan secara tatap muka serta dikemas dalam seting informal. Proses yang dilakukan selama coaching antara lain, melakukan identifikasi ulang permasalah yang ada di desa sabrang Ambulu, melakukan pengkajian peran dan fungsi kelompot PPT Desbumi Harmoni dalam meningkatkan produk karya hasil pemanfaatan potensi lokal menjadi barang/ produk yang memiliki nilai lebih menyusul produk-produk lain yang sudah dihasilkan oleh pemberdayaan perempuan mantan buruh migran ini.

\section{PENUTUP}

Pelatihan inovasi ini telah berkontribusi pada peningkatan keterampilan masyarakat di Desa Sabrang, Kecamatan Ambulu, Kabupaten Jember. Serangkaian usaha telah dilakukan guna meningkatkan peningkatan nilai produk lokal agar dapat memiliki nilai ekonomi. Pemberdayaan ini merupakan langkah awal yang masih membutuhan pemberdayaan lebih lanjut. Peran pemerintah sangat dibutuhkan dalam rangka mendukung keterampilan yang telah dimiliki oleh masyarakat. Pemberdayaan lanjutan perlu dilakukan dalam hal strategi ekonomi, seperti pengemasan dan pemasaran produk sehingga produk yang telah dihasilkan oleh masyarakat dapat menambah produk unggulan yang dimiliki oleh Kabupaten Jember.

\section{DAFTAR PUSTAKA}

Boyle,P.G.1981. Planning Better Program. New York: McGraw-Hill Book Company. Desa Peduli Buruh Migran (DESBUMI) http://migrantcare.net/desbumi/ diakses pada 07 september 2018 pukul 11.03 WIB.

Membangun Desa Peduli Buruh Migran di Indramayu. Kabar Migrant CARE edisi 05 Agustus 2018 http://migrantCARE.net/membangun-desa-peduli- buruhmigran-di-indramayu/ diakses 07/09/2018 jam 22.13 WIB.

Migrant CARE : Segera Revisi UU TKI 2013 http://www.antarakalbar.com/berita/309269/migrant-CARE-segera-revisiuu-tki-2013 diakses, 5/09/2018 jam 13.25 WIB.

Moedzakir, Djauzi M. 2010. Metode Pembelajaran Untuk Program-Program Pendidikan Luar Sekolah. Malang : Universitas Negeri Malng Press.

Mohammad Ashari dkk, 2016-2017. Buku Profil Desa sabrang kecamatan Ambulu. Jember: Tidak Diterbitkan. 
Lampiran 1. Gambar Lokasi Mitra

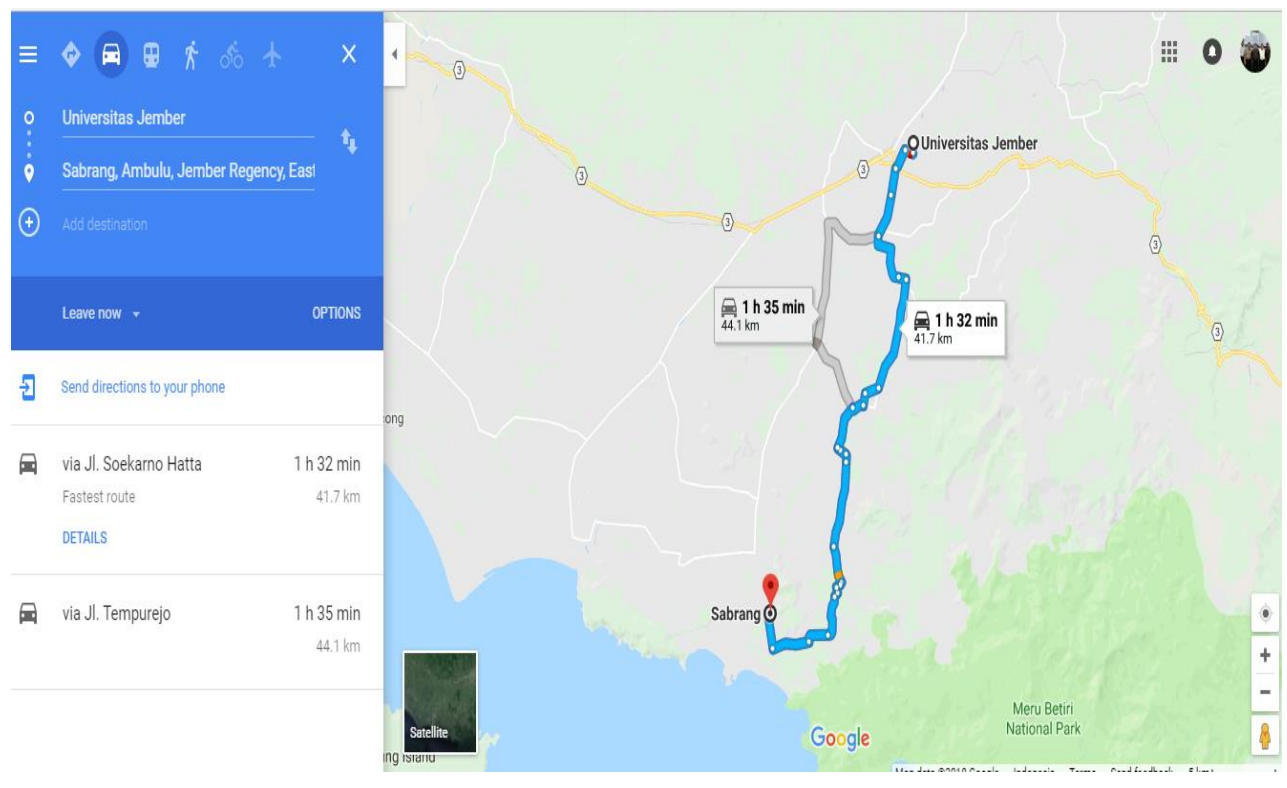

Lampiran 2. Pertanian Pepaya California di Desa Sabrang

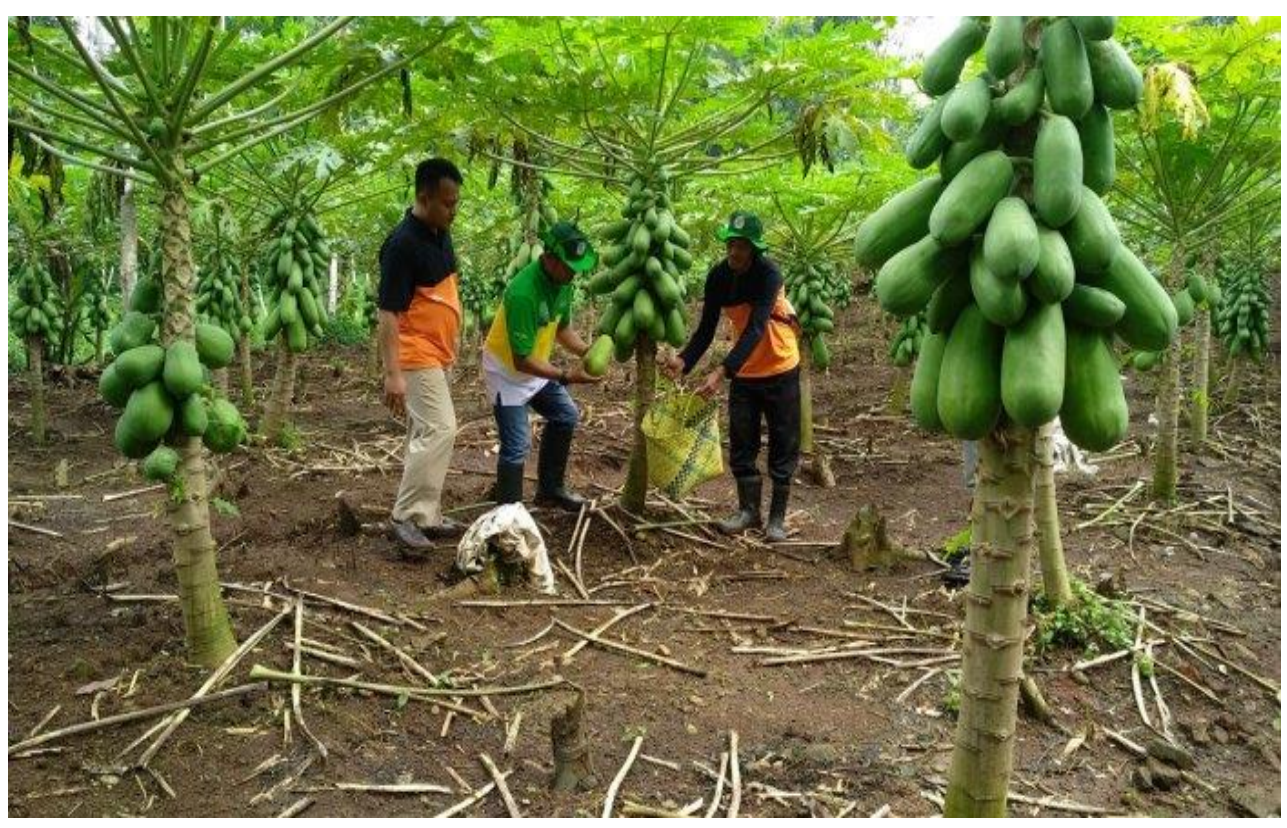


Lampiran 3. Kegiatan Pelatihan Kewirausahaan Pembuatan Sabun Pepaya

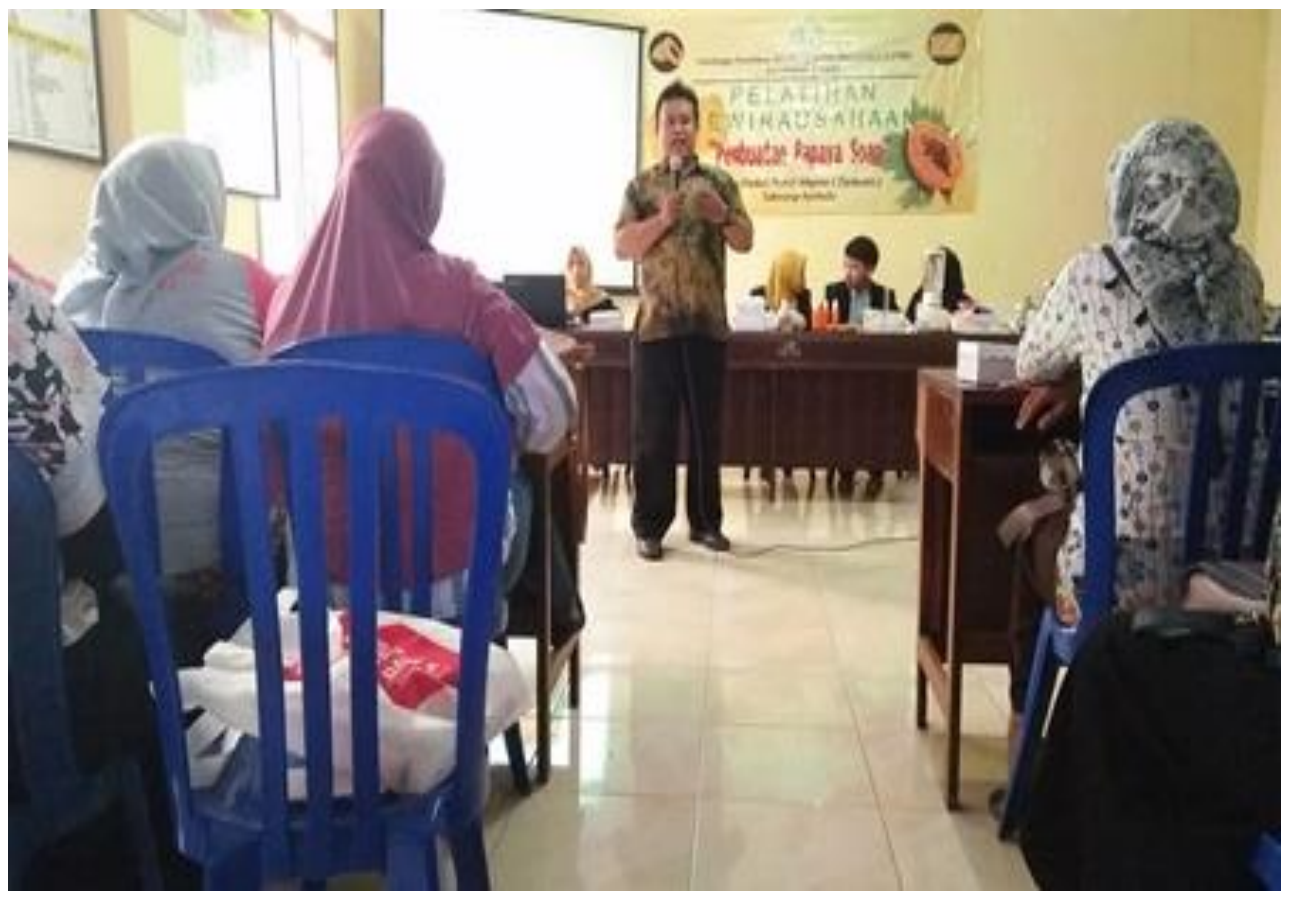

Lampiran 4. Hasil Produk Pelatihan Sabun Pepaya

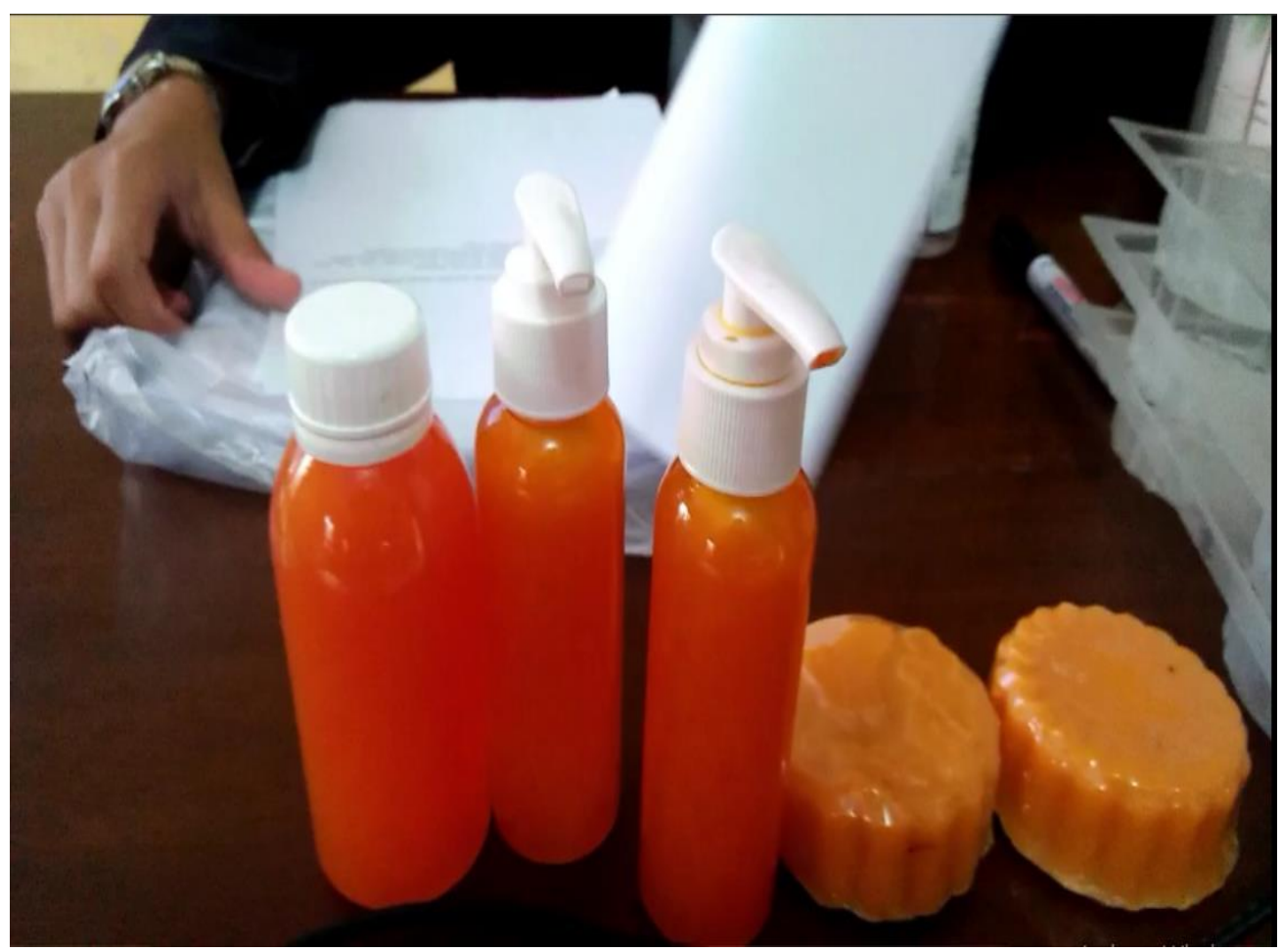


Lampiran 5. Pendampingan Kegiatan Pengabdian PPT Desbumi Harmoni

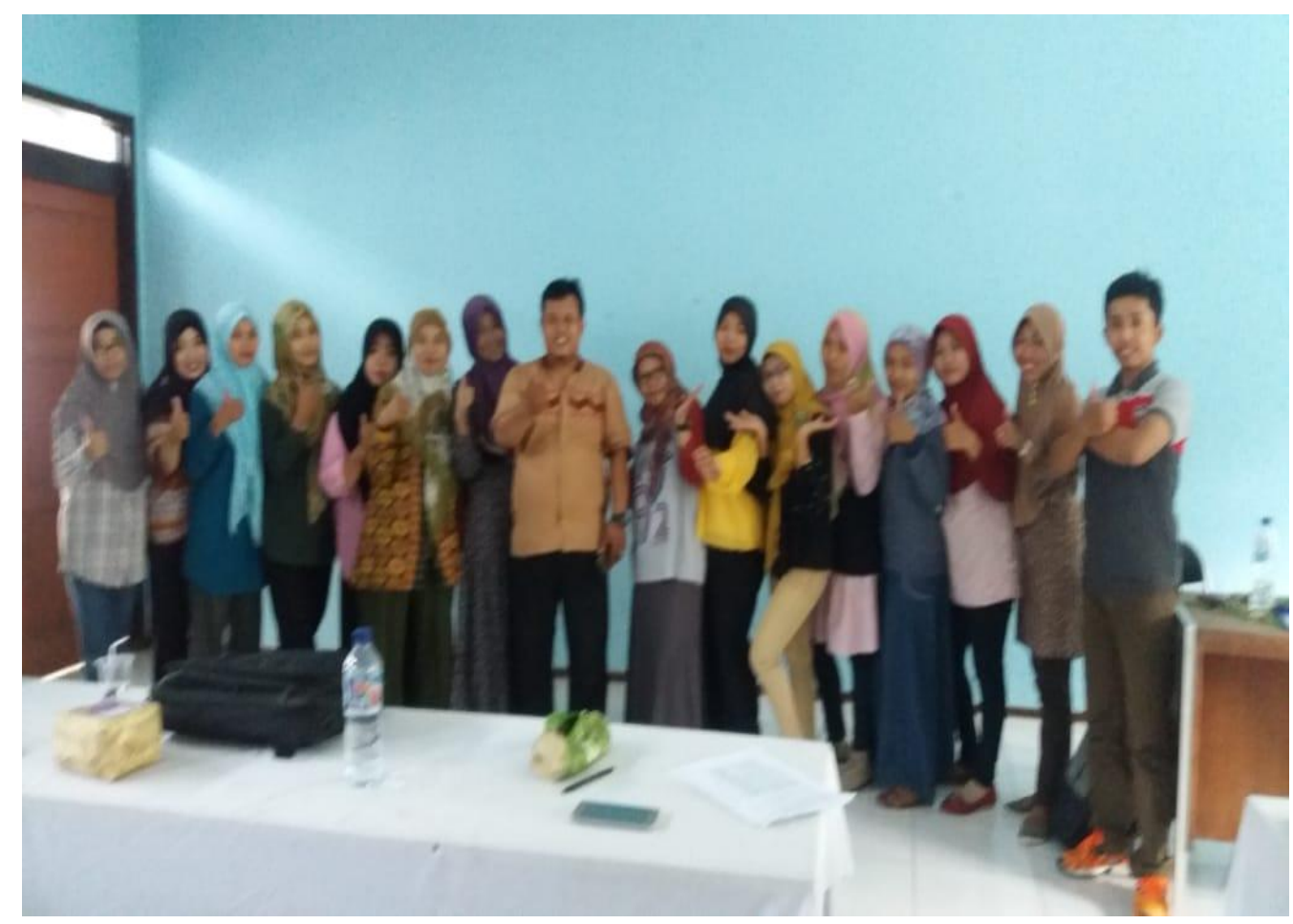

Lampiran 6. Pendampingan Kegiatan Pengabdian Kewirausahaan

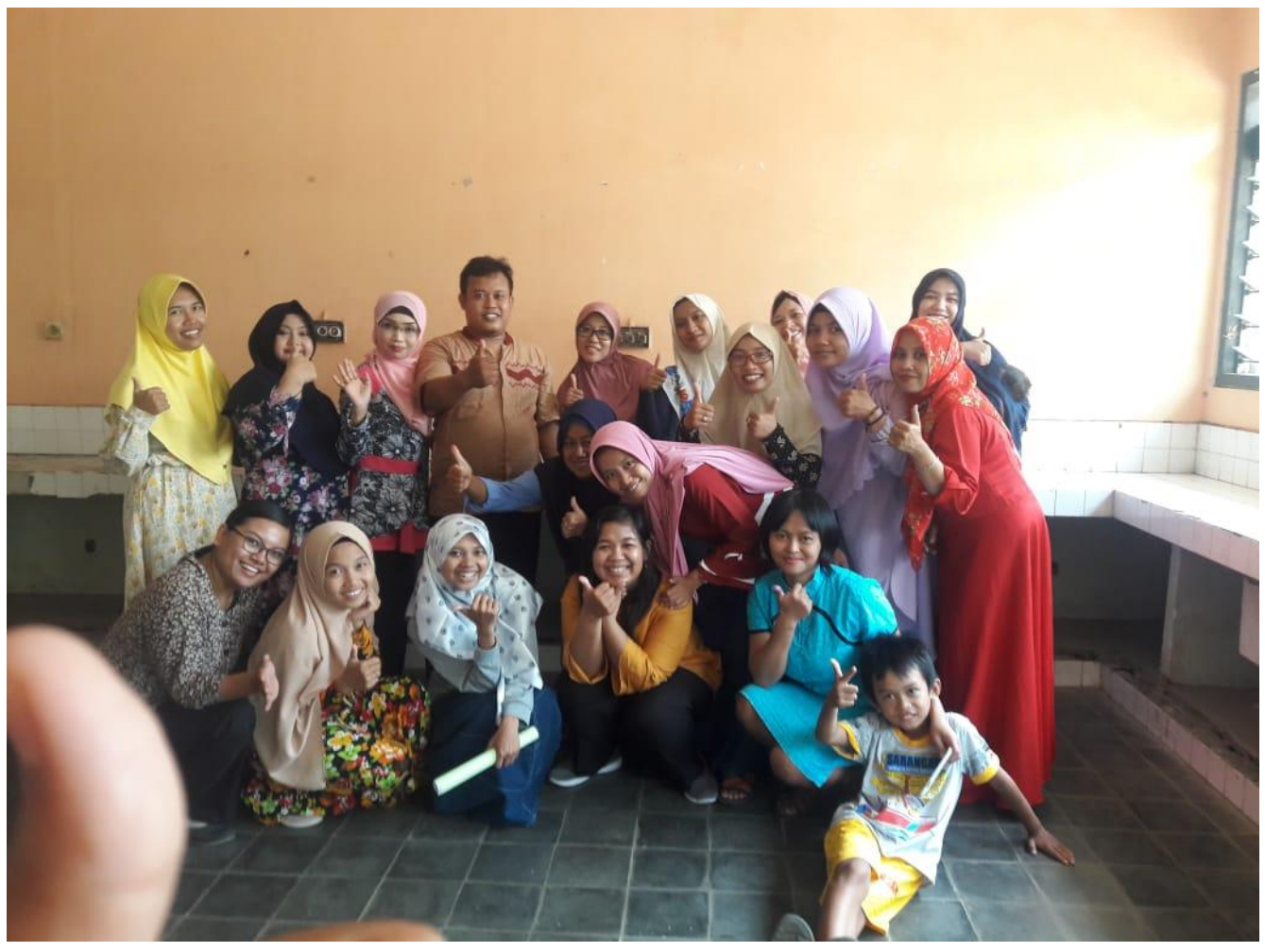

